\title{
Nutritional status of under-five children born to teenage mothers in an urban setting, south-western Nigeria
}

\author{
Monday Daniel Olodu* ${ }^{0}$, Adewunmi Grace Adeyemi, Samuel Anu Olowookere and Olapeju Adefunke Esimai
}

\begin{abstract}
Objective: There have been many studies on the nutritional status of under-fives and factors responsible but very few looks at this special group of women. This study assessed the breastfeeding practices of teenage mothers and determined its association with the nutritional indices of their under-five children. The study was a descriptive crosssectional survey. A total of 300 mother-child pair was selected using a multi-stage sampling technique from Primary Health Care centres in Ondo West Local Government Area, Ondo State, Nigeria. Bivariate and multivariate logistic regression were done to identify predictors' of poor nutritional status at $\mathrm{p}<0.05$.

Results: About $87 \%$ initiated breastfeeding less than $1 \mathrm{~h}$ after birth while $31.9 \%$ breastfed their children exclusively for 6 months. Prevalence of stunting, wasting and underweight among the under-fives were $18.6 \%, 25.3 \%$, and $29.5 \%$ respectively. Initiation of breastfeeding more than $1 \mathrm{~h}$ after birth increased the odds of stunting $(\mathrm{OR}=9.551$, $\mathrm{Cl}=1.279-16.310)$ and underweight $(\mathrm{OR}=6.674, \mathrm{Cl}=3.159-14.097)$ by about 10 and 7 times respectively. Whereas odds of wasting ( $\mathrm{OR}=2.346, \mathrm{Cl}=1.228-4.480)$ was 2 times higher with breastfeeding duration less than 6 months. Therefore, education of teenage mothers on breastfeeding initiation and duration is vital in reducing malnutrition among under-fives.
\end{abstract}

Keywords: Nutritional status, Teenage mothers, Breastfeeding practice, Under-fives

\section{Introduction}

Malnutrition is a teething public health problem affecting mostly the under-five children living in developing countries [1]. The 2013 Nigeria Demographic and Health Survey (NDHS) [2], revealed that $37 \%$ of children under the age of five are stunted, while $21 \%$ are severely stunted, eighteen percent of under-five children in Nigeria are considered wasted and $9 \%$ are severely wasted while $29 \%$ are underweight, with $12 \%$ being severely underweight. The under-five mortality rate in Nigeria is $128 / 1000$ live birth which is among the world's highest [2].

Child care is one of the key underlying causes of childhood malnutrition. Child care is manifested in the way a child is fed, nurtured, socialized and guided. It is practised by women who carry out some of the care activities

\footnotetext{
*Correspondence: mondayolodu@gmail.com
}

Community Health Department, Obafemi Awolowo University, Ile-Ife,

Osun State, Nigeria such as breastfeeding and feeding of young children; psychosocial stimulation of children and support for their development; complementary food preparation, feeding and storage practices; hygiene practices and care for a child during illness and adoption of health seeking practices [3]. The complexity of child care requires that every woman must be adequately prepared to succeed in the responsibilities. However, every year, an estimated 21 million girls aged 15 to 19 years, and 2 million girls aged under 15 years become pregnant in developing countries $[4,5]$. Evidence has shown that teenage pregnancy in Nigeria does not only account for high birth rate for teenagers, but that the incidence of pregnancy among female teenagers in Nigeria is increasing rapidly. In fact, the 2013 NDHS [2] showed that $23 \%$ of women aged 15-19 years have already begun childbearing.

Studies have shown that the high rate of teenage pregnancy contributes significantly to the high prevalence of malnutrition among under-five children [6, 7]. Maternal 
factors such as age, education, family size and marital status have also been found to significantly influence the nutritional status of their under-five children $[8,9]$. Poor breastfeeding and complementary feeding practices also play key roles in determining the nutritional status of under-five children. In Nigeria, only $17 \%$ of children below 6 months are exclusively breastfed while $10 \%$ of children aged 6-23 months are fed appropriately based on recommended infant and young child feeding (IYCF) practices [2]. Poor nutritional status, especially among children, have negative effects on their health and development during the early years of life $[10,11]$.

There have been many studies on nutritional status of under-five children and factors responsible but very few looks at this special group of women, their breastfeeding practice and its influence on the nutritional status of their under-fives. This study, therefore, assessed the breastfeeding practices of teenage mothers, nutritional status of their under-five children and determined the association between breastfeeding practice and nutritional indices of children born to teenage mothers in an urban setting, south-western, Nigeria.

\section{Main text \\ Methods \\ Setting and design}

This facility based descriptive cross-sectional study was conducted at Primary Health Care (PHCs) centres, Ondo West Local Government Area (LGA), Ondo State, Nigeria from February 2017 to March 2017. Ondo West Local Government is located on Latitude $7.1^{\circ}$ North and Longitude $4.83^{\circ}$ East and $277 \mathrm{~m}$ above the sea level. It is primarily inhabited by the Yoruba ethnic group though there are other ethnic groups such as Igbo and Hausa. The two major religions are Islam and Christianity. The town consists majorly of civil servants, businessmen, artisans and students of various institutions such as Federal College of Education, State University (University of Medical Sciences) and Private University (Wesley). There are five major government health facilities in Ondo West LGA namely; Mother and Child Hospital, Trauma and Surgical Centre, Kidney Care Centre, State Specialist Hospital and Forty-four Primary Health Care (PHCs) centres.

\section{Participants}

All teenage mothers in Ondo West LGA with at least one under-five child was eligible for the study.

\section{Sample size determination and sampling technique}

The sample size was calculated using Leslie Fischer's formula for a single population proportion $\left[n=Z^{2} p(1-p) /\right.$ $\left.\mathrm{d}^{2}\right]$. The prevalence of malnutrition among under five was $23.6 \%$ from a previous study [12], with a $95 \%$ CI and precision of 5\%. After accounting for a non-response rate of $10 \%$, the total sample size was rounded up to 300 . Multi-stage sampling technique was used in selecting participants. In the first stage, out of twelve wards, seven were selected by simple random sampling technique (balloting method). In the second stage, twenty-two PHCs were purposively selected from the forty-four available PHCs in the selected wards based on locations, sizes and services offered. The third stage involve the selection of teenage mothers with at least one under-five child attending the centres to access any service by simple random sampling technique.

\section{Data collection tools and technique}

A structured interviewer-administered questionnaire was used to collect data. The questionnaire had four sections which assessed the respondents' socio-demographic characteristics, Index child characteristics, breastfeeding practices and nutritional status of the index child using anthropometric measurements. The questionnaire was pretested among teenage mothers attending General Out-patient Clinic and Immunization Clinic at State Specialist Hospital, Ondo. The instrument was translated into the local language (Yoruba) and back-translated to English language. Five research assistants were recruited and trained for 2 days to assist with data collection. Breastfeeding practices of teenage mothers were determined by assessing the time of initiation of breastfeeding and the duration of exclusive breastfeeding. Nutritional status of the under-five children was generated based on the output from the World Health Organization (WHO) Anthro software. WHO standard classification was used to categorize the nutritional status of the under-five children [11].

\section{Data analysis}

Data collected were analyzed using the Statistical Package for Service Solution (SPSS version 20). Socio demographic, breastfeeding practices and nutritional status of participants were presented in texts and tables. Bivariate analysis was done to determine the association between teenage mothers' breastfeeding practices and the nutritional indices of the under-five children, and variables with $\mathrm{p}<0.2$ were included in the multivariate logistic regression model. In the multivariate analysis, predictors with $\mathrm{p}<0.05$ were considered statistically significant.

\section{Results}

Socio-demographic characteristics of the study participants

The sample consisted of 300 mother-child pair who started the survey with 285 completing it. This gave a response rate of $95 \%$. Most (84.2\%) of the mothers are aged $18-19$ years, $54.7 \%$ delivered their first child at age 
17 years and $90.5 \%$ of the mothers have one under-five child. Majority $(81.1 \%)$ are of Yoruba tribe and practice Islam (48.4\%). Forty per cent $(40 \%)$ had primary education and are mostly traders (77.5\%). About $93.7 \%$ of the respondent household income per month was more than 20,000 naira. All respondents breastfed their children. Majority (87\%) initiated breastfeeding in less than $1 \mathrm{~h}$ while $31.9 \%$ breastfeed their children exclusively for 6 months (Table 1 ).

\section{Nutritional status of under-five children of teenage mothers}

The mean age of the children was $32.9( \pm 5)$ months. The average weights and heights were $14.67( \pm 2) \mathrm{kg}$ and $67.36( \pm 4) \mathrm{cm}$ respectively. Majority $(73.4 \%)$ of the children were undernourished, almost $10 \%$ were over-nourished and less than $20 \%$ were having normal nutritional status. Among the undernourished, the prevalence of underweight was the highest (29.5\%), followed by wasting (25.3\%) and stunting (18.6\%) (Table 2).

Relationship between breastfeeding practices and nutritional status

There are statistically significant relationships between breastfeeding initiation time and occurrence of stunting $\left(\chi^{2}=7.095, \mathrm{p}=0.008\right)$, and underweight $\left(\chi^{2}=29.684\right.$, $\mathrm{p}=0.001)$ in under-five children. Duration of breastfeeding was found to be statistically significant to the occurrence of wasting $\left(\chi^{2}=6.910, p=0.009\right)$ in under-fives. Logistic regression further showed that teenage mothers who breastfed after 1-h of birth are ten times more likely to have stunted children and almost seven times more likely to have underweight children compared to those who breastfed early. Also, children born to mothers who practised exclusive breastfeeding for less than 6 months are two times more likely to be wasted compared to those who exclusively breastfed for 6 months (Table 3).

\section{Discussion}

All the respondents breastfed their under-five children at different times after birth. This agrees with a study in Salisbury where more mothers also breastfed after birth [13]. The result of this study was much higher than the report of $35 \%$ of mothers who decided to breastfeed in a previous study [9]. Similarly, it was above $38 \%$ breastfeeding prevalence in another study [14]. However, our finding agrees with the $80 \%$ and $90 \%$ reported by Smith et al. [15] and Chatman et al. [16] respectively in their previous study. The high prevalence of breastfeeding reported in this study might have resulted from constant health talks that they are exposed to during ante-natal clinics and the free medical care initiated by the State [17].

Eighty-seven per cent of our respondents initiated breastfeeding within $1 \mathrm{~h}$ after birth. This was much

\begin{tabular}{|c|c|c|}
\hline Variables & $\begin{array}{l}\text { Frequency } \\
(n=285)\end{array}$ & Percentage (\%) \\
\hline \multicolumn{3}{|l|}{ Age (years) } \\
\hline $15-17$ & 45 & 15.8 \\
\hline $18-19$ & 240 & 84.2 \\
\hline \multicolumn{3}{|c|}{ Age at delivery of first child } \\
\hline 15 & 27 & 9.5 \\
\hline 16 & 102 & 35.8 \\
\hline 17 & 156 & 54.7 \\
\hline \multicolumn{3}{|c|}{ Number of under-five children } \\
\hline One & 258 & 90.5 \\
\hline Two & 27 & 9.5 \\
\hline \multicolumn{3}{|l|}{ Ethnicity } \\
\hline Hausa & 18 & 6.3 \\
\hline lgbo & 36 & 12.6 \\
\hline Yoruba & 231 & 81.1 \\
\hline \multicolumn{3}{|l|}{ Religion } \\
\hline Christianity & 128 & 44.9 \\
\hline Islam & 138 & 48.4 \\
\hline Traditional & 19 & 6.7 \\
\hline \multicolumn{3}{|c|}{ Level of education } \\
\hline None & 25 & 8.8 \\
\hline Primary & 114 & 40.0 \\
\hline Secondary & 74 & 26.0 \\
\hline Tertiary & 72 & 25.2 \\
\hline \multicolumn{3}{|l|}{ Occupation } \\
\hline Full housewife & 9 & 2.8 \\
\hline Trading & 221 & 77.5 \\
\hline Artisan & 18 & 6.7 \\
\hline Farming & 37 & 13.0 \\
\hline \multicolumn{3}{|c|}{ Household income/month } \\
\hline$<20,000$ & 18 & 6.3 \\
\hline$>20,000$ & 267 & 93.7 \\
\hline \multicolumn{3}{|l|}{ Breastfeeding } \\
\hline \multicolumn{3}{|c|}{ Did you breastfeed your child? } \\
\hline Yes & 285 & 100 \\
\hline \multicolumn{3}{|c|}{ Initiation of breastfeeding (h) } \\
\hline$<1$ & 248 & 87.0 \\
\hline$>1$ & 37 & 13.0 \\
\hline \multicolumn{3}{|c|}{ Duration of exclusive BF (months) } \\
\hline$<4$ & 45 & 15.8 \\
\hline $4-5$ & 149 & 52.3 \\
\hline 6 & 91 & 31.9 \\
\hline
\end{tabular}

higher than what was previously reported by the State in 2013 [2] and even higher than 35.1\% reported by Park et al. [18] in their study among teenage mothers. The finding agrees with $80 \%$ reported by Chatman et al. [16] in a previous study among Jamaican mothers. 
Table 2 Anthropometry and nutritional status of underfive children of teenage mothers $(n=285)$

\begin{tabular}{|c|c|c|}
\hline Variables & Frequency (n) & Percentage (\%) \\
\hline \multicolumn{3}{|l|}{ Age (months) } \\
\hline $6-17$ & 74 & 26.0 \\
\hline $18-35$ & 64 & 22.5 \\
\hline $36-60$ & 147 & 51.5 \\
\hline \multicolumn{3}{|l|}{ Mean $=32.9 \pm 5$} \\
\hline \multicolumn{3}{|l|}{ Weight (kg) } \\
\hline $10-12$ & 46 & 16.1 \\
\hline $13-15$ & 120 & 42.1 \\
\hline $16-18$ & 119 & 41.8 \\
\hline \multicolumn{3}{|l|}{ Mean $=14.67 \pm 2$} \\
\hline \multicolumn{3}{|l|}{ Height $(\mathrm{cm})$} \\
\hline$\leq 50$ & 46 & 16.1 \\
\hline $51-60$ & 46 & 16.1 \\
\hline $61-70$ & 130 & 45.7 \\
\hline$\geq 71$ & 63 & 22.1 \\
\hline \multicolumn{3}{|c|}{ Mean $=67.36 \pm 4$} \\
\hline \multicolumn{3}{|l|}{ Nutritional status } \\
\hline Normal & 48 & 16.8 \\
\hline Over-nutrition & 28 & 9.8 \\
\hline Under-nutrition & 209 & 73.4 \\
\hline \multicolumn{3}{|l|}{ *Undernutrition } \\
\hline Stunted & 53 & 18.6 \\
\hline Wasted & 72 & 25.3 \\
\hline Underweight & 84 & 29.5 \\
\hline
\end{tabular}

*The proportions of undernutrition totaled $73.4 \%$ (209/285)

For optimal growth, it is recommended that infants be exclusively breastfed for the first 6 months of life [19]. Ninety-one (31.9\%) of the respondents breastfed their children exclusively for 6 months. This finding was higher than the report in previous studies among older mothers in Nasarawa, Ondo and Osun States, where the prevalence of exclusive breastfeeding was $18.1 \%, 16.7 \%$ and $16.4 \%$ respectively [20-22]. However, the finding agreed with the prevalence of $30.1 \%$ of exclusive breastfeeding in a study conducted in Zambia [23]. The high prevalence of exclusive breastfeeding may have been influenced by constant nutrition education and health benefits of breast milk that they are exposed to during ante-natal clinics. Unfortunately, it was observed that majority of the participants could not sustain their desire to exclusively breastfed for 6 months.
The prevalence of malnutrition among under-five children born to teenage mothers was very high. Four out of five (83.1\%) of these children are malnourished. The most prevalent form of malnutrition among them was undernutrition $(73.4 \%)$. This finding agreed with the findings of other researchers [24, 25] showing that malnutrition is indeed a teething public health problem among under-fives. The prevalence of underweight, wasting and stunting in this study was higher than the prevalence of underweight (25\%), wasting (9.4\%) and stunting (19.2\%) among under-fives in a study in Bangladesh [26]. The prevalence reported in the present study was low compared to the prevalence of underweight (33.3\%), wasting (26.4\%) and stunting (24.6\%) reported in a previous study [24]. The findings support the view that the prevalence of malnutrition among under-five children is still high in many developing countries [12]. The problem is further compounded by teenage motherhood who are not yet adequately prepared to shoulder the responsibility of childcare which is one of the causes of childhood malnutrition [27].

The association between breastfeeding practices and nutritional indices of under-five children showed that early initiation of breastfeeding was associated with a lower prevalence of stunting and underweight among under-five children. This agreed with the report that better child feeding practices were associated with higher HAZ among 12- to 36-month-old children in research conducted by Ruel and Purnima [28] among Latin Americans. Also, this study showed that breastfeeding exclusively for 6 months is associated with lower prevalence of wasting among under-fives. This agreed with the finding of another researcher [24] who concluded that children who did not receive appropriate feeding had higher odds for wasting, stunting and underweight.

\section{Conclusion}

This study shows that undernutrition is the most prevalent form of malnutrition among the under-fives of teenage mothers. Although many initiated breastfeeding on time, but could not sustain the practice for 6 months. Also, the risk of stunting and underweight increases with late initiation of breastfeeding at birth while the risk of wasting increases with exclusive breastfeeding duration less than 6 months. Therefore, education of teenagers on the consequences of early motherhood and helping sexually active teenagers in meeting their contraceptive 
Table 3 Relationship between breastfeeding practices and nutritional indices of under-five children of teenage mothers $(\mathrm{n}=\mathbf{2 8 5})$

\begin{tabular}{|c|c|c|c|c|c|}
\hline \multirow[t]{2}{*}{ Variables } & \multicolumn{2}{|l|}{ Height for age } & \multirow[t]{2}{*}{ Total } & \multirow[t]{2}{*}{$\chi^{2}$} & \multirow[t]{2}{*}{$p$-value } \\
\hline & Stunting & Normal & & & \\
\hline \multicolumn{6}{|l|}{ BF Initiation } \\
\hline$\leq 1 \mathrm{~h}$ & $52(21.0)$ & $196(79.0)$ & $248(100)$ & \multirow[t]{2}{*}{7.095} & \multirow[t]{2}{*}{$0.008^{*}$} \\
\hline$>1 \mathrm{~h}$ & $1(2.7)$ & $36(97.3)$ & $37(100)$ & & \\
\hline \multicolumn{6}{|l|}{ BF Duration } \\
\hline$<6$ months & $37(19.1)$ & $157(80.9)$ & $194(100)$ & \multirow[t]{2}{*}{0.091} & \multirow[t]{2}{*}{0.763} \\
\hline 6 months & $16(17.6)$ & $75(82.4)$ & $91(100)$ & & \\
\hline \multirow[t]{2}{*}{ Variables } & \multicolumn{2}{|l|}{ Weight for age } & \multirow[t]{2}{*}{ Total } & \multirow[t]{2}{*}{$x^{2}$} & \multirow[t]{2}{*}{ p-value } \\
\hline & Underweight & Normal & & & \\
\hline \multicolumn{6}{|l|}{ BF Initiation } \\
\hline$\leq 1 \mathrm{~h}$ & $59(23.8)$ & $189(76.2)$ & $248(100)$ & \multirow[t]{2}{*}{29.684} & \multirow[t]{2}{*}{$0.001^{*}$} \\
\hline$>1 \mathrm{~h}$ & $25(67.6)$ & $12(32.4)$ & $37(100)$ & & \\
\hline \multicolumn{6}{|l|}{ BF Duration } \\
\hline$<6$ months & $56(28.9)$ & $138(71.1)$ & $194(100)$ & \multirow[t]{2}{*}{0.108} & \multirow[t]{2}{*}{0.742} \\
\hline 6 months & $28(30.8)$ & $63(69.2)$ & $91(100)$ & & \\
\hline \multirow[t]{2}{*}{ Variables } & \multicolumn{2}{|c|}{ Weight for height } & \multirow[t]{2}{*}{ Total } & \multirow[t]{2}{*}{$\mathrm{X}^{2}$} & \multirow[t]{2}{*}{$p$-value } \\
\hline & Wasted & Normal & & & \\
\hline \multicolumn{6}{|l|}{ BF Initiation } \\
\hline$\leq 1 \mathrm{~h}$ & $63(25.4)$ & $185(74.6)$ & $248(100)$ & \multirow[t]{2}{*}{0.020} & \multirow[t]{2}{*}{0.888} \\
\hline$>1 \mathrm{~h}$ & $9(24.3)$ & $28(75.7)$ & $37(100)$ & & \\
\hline \multicolumn{6}{|l|}{ BF Duration } \\
\hline$<6$ months & $58(29.9)$ & $136(70.1)$ & $194(100)$ & \multirow[t]{2}{*}{6.910} & \multirow[t]{2}{*}{$0.009^{*}$} \\
\hline 6 months & $14(15.4)$ & 77 (84.6) & $91(100)$ & & \\
\hline Variables & & tio (OR) & & & p-value \\
\hline
\end{tabular}

Predictors of nutritional indices of under-fives

\section{Predictor of stunting}

Breastfeeding initiation time

\begin{tabular}{lll}
$>1 \mathrm{~h}$ & 9.551 & $1.279-16.310$ \\
$\leq 1 \mathrm{~h}$ (Ref) & 1 & \\
$\begin{array}{l}\text { Predictor of underweight } \\
\text { Breastfeeding initiation time }\end{array}$ & & \\
$>1 \mathrm{~h}$ & 6.674 & $3.159-14.097$ \\
$\leq 1 \mathrm{~h}$ (Ref) & 1 & \\
$\begin{array}{l}\text { Predictor of wasting } \\
\text { Duration of exclusive BF }\end{array}$ & & \\
\hline $\begin{array}{l}\text { months } \\
<6 \text { months (Ref) }\end{array}$ & 2.346 & $1.228-4.480$ \\
\hline
\end{tabular}

$B F$ breastfeeding

*Significance

needs and uptake will help to curb the problem of teenage pregnancy and reduce the high prevalence of underfive malnutrition.

\section{Limitation of the study}

The study sample size is small which may affect the generalizability of results, and there is a likelihood of a recall bias as responses were self-reported. 


\begin{abstract}
Abbreviations
BMI: Body Mass Index; IYCF: infant and young child feeding; NDHS: Nigeria Demographic and Health Survey; PHCs: Primary Health Care; SD: standard deviation;WHO: World Health Organization.
\end{abstract}

\section{Authors' contributions}

EOA, OSA and OMD make substantial contributions to the conception and design of the study while AAG makes vital contribution in the implementation. All authors were involved in data collection, analysis and interpretation. All authors read and approved the final manuscript.

\section{Acknowledgements}

We thank the Local Government Primary Health Care Board and the management of the Primary Health Care Centres of Ondo State and their staff for granting permission to conduct the study, as well as all the participants who took part in the study.

\section{Competing interests}

The authors declare that they have no competing interests.

\section{Availability of data and materials}

The datasets used during the current study are available from the corresponding author on reasonable request.

\section{Consent for publication}

Not applicable.

\section{Ethics approval and consent to participate}

Ethical clearance was obtained from the Institute of Public Health Research and Ethics Committee, Obafemi Awolowo University, Ile-Ife, Nigeria. At the Health centres, permission was sought from the Community Health Nurse and Medical Officer in charge. Written informed consent was obtained from the parents or guardian of participants who accompanied them to the health facility and assent was obtained from teenage mothers during the time of the study.

\section{Funding}

This research did not receive any specific funds from any agencies. It was selffunded by the authors.

\section{Publisher's Note}

Springer Nature remains neutral with regard to jurisdictional claims in published maps and institutional affiliations.

Received: 13 January 2019 Accepted: 21 February 2019

Published online: 04 March 2019

\section{References}

1. United Nation Children's Fund (UNICEF). Levels and trends in child malnutrition. eSocialSciences. 2018.

2. National Population Commission (NPC) [Nigeria] and ICF International. Nigeria Demographic and Health Survey 2013. Abuja and Rockville: NPC and ICF International; 2014.

3. Engle PL, Menon P, Haddad L. Care and nutrition: concepts and measurement. World Dev. 1999;27(8):1309-37.

4. Darroch JE, Woog V, Bankole A, Ashford LS. Adding it up: costs and benefits of meeting the contraceptive needs of adolescents. 2016.

5. Blum RW, Gates Sr W. Girlhood not motherhood. Preventing adolescent pregnancy. 2015.

6. Finlay JE, Özaltin E, Canning D. The association of maternal age with infant mortality, child anthropometric failure, diarrhoea and anaemia for first births: evidence from 55 low-and middle-income countries. BMJ Open. 2011;1(2):e000226.

7. Abrahams Z, Mchiza Z, Steyn NP. Diet and mortality rates in subSaharan Africa: stages in the nutrition transition. BMC Public Health. 2011:11(1):801.

8. Nyaruhucha C, Msuya J, Mamiro P, Kerengi A. Nutritional status and feeding practices of under-five children in Simanjiro District, Tanzania Tanzania J Health Res. 2006;8(3):162.

9. Wiemann CM, DuBois JC, Berenson AB. Racial/ethnic differences in the decision to breastfeed among adolescent mothers. Pediatrics. 1998;101(6):e11.

10. Prado EL, Dewey KG. Nutrition and brain development in early life. Nutr Rev. 2014;72(4):267-84.

11. Grantham-McGregor SM, Fernald LC, Sethuraman K. Effects of health and nutrition on cognitive and behavioural development in children in the first three years of life. Part 1: Low birthweight, breastfeeding, and protein-energy malnutrition. Food Nutr Bull. 1999;20(1):53-75.

12. Babatunde RO, Olagunju FI, Fakayode SB, Sola-Ojo FE. Prevalence and determinants of malnutrition among under-five children of farming households in Kwara State, Nigeria. J Agric Sci. 2011;3(3):173.

13. Salt MJ, Law CM, Bull AR, Osmond C. Determinants of breastfeeding in Salisbury and Durham. J Public Health. 1994;16(3):291-5.

14. Bica OC, Giugliani ERJ. Influence of counseling sessions on the prevalence of breastfeeding in the first year of life: a randomized clinical trial with adolescent mothers and grandmothers. Birth. 2014:41(1):39-45.

15. Smith PH, Coley SL, Labbok MH, Cupito S, Nwokah E. Early breastfeeding experiences of adolescent mothers: a qualitative prospective study. Int Breastfeed J. 2012;7(1):13.

16. Chatman LM, Salihu HM, Roofe ME, Wheatle P, Henry D, Jolly PE. Influence of knowledge and attitudes on exclusive breastfeeding practice among rural Jamaican mothers. Birth. 2004:31(4):265-71.

17. Okonofua F, Lambo E, Okeibunor J, Agholor K. Advocacy for free maternal and child health care in Nigeria_-results and outcomes. Health Policy. 2011;99(2):131-8.

18. Park YK, Meier ER, Song WO. Characteristics of teenage mothers and predictors of breastfeeding initiation in the Michigan WIC program in 1995. J Hum Lactat. 2003;19(1):50-6.

19. World Health Organization (WHO). Guideline: protecting, promoting and supporting breastfeeding in facilities providing maternity and newborn services. Geneva: World Health Organization; 2017.

20. Awogbenja MD, Ndife J. Evaluation of infant feeding and care practices among mothers in nassarawa eggon local government area of Nasarawa state. Indian J Sci Res. 2012;3(1):21

21. Akorede QJ, Abiola OM. Assessment of nutritional status of under five children in Akure South Local Government, Ondo State Nigeria. Int J Res Rev Appl Sci. 2013:14(3):671.

22. Oladoyinbo C, Makanjuola O, Sobo A. Breastfeeding pattern and nutritional status of children under two years in Oshogbo Local Government Area Osun State Nigeria. Nigerian J Paediatr. 2016;43(3):186-92.

23. Katepa-Bwalya M, Mukonka V, Kankasa C, Masaninga F, Babaniyi O, Siziya S. Infants and young children feeding practices and nutritional status in two districts of Zambia. Int Breastfeeding J. 2015;10(1):5.

24. Udoh EE, Amodu OK. Complementary feeding practices among mothers and nutritional status of infants in Akpabuyo Area, Cross River State Nigeria. SpringerPlus. 2016;5(1):2073.

25. Rao VG, Yadav R, Dolla CK, Kumar S, Bhondeley MK, Ukey M. Undernutrition \& childhood morbidities among tribal preschool children. Indian J Med Res. 2005;122(1):43.

26. Farah S, Karim M. Characteristics of feeding practices and nutritional status of infants in selected villages at Dhamrai. Bangladesh Med Res Counc Bull. 2015;41(3):108-13.

27. United Nation's Children Fund (UNICEF). Strategy for improved nutrition of children and women in developing countries. New York: UNICEF; 1990.

28. Ruel MT, Menon P. Child feeding practices are associated with child nutritional status in Latin America: innovative uses of the demographic and health surveys. J Nutr. 2002;132(6):1180-7. 